\title{
Exploration of an innovative draw solution for a forward osmosis-membrane distillation desalination process
}

\author{
Nguyen Cong Nguyen ${ }^{1,2}$, Shiao-Shing Chen ${ }^{1}$, Shubham Jain ${ }^{3}$, Hau Thi Nguyen ${ }^{1,2}$, Saikat Sinha Ray ${ }^{1}$, \\ Huu Hao $\mathrm{Ngo}^{4}$, Wenshan Guo ${ }^{4}$, Ngoc Tuan Lam ${ }^{2}$, Hung Cong Duong 5 \\ ${ }^{1}$ Institute of Environmental Engineering and Management, National TaipeiUniversityof Technology, No.I, Sec. 3, Chung-H siao \\ E. Rd, Taipei 106, Taiwan, Republic of China \\ ${ }^{2}$ Faculty of Environment and $N$ atural Resources, Dalat University, Dalat, Vietnam \\ ${ }^{3}$ School of Civiland Chemical Engineering, VIT University, Vellore, India \\ ${ }^{4}$ School of Civiland Environmental Engineering, Facultyof Engineering and Information Technology, Universityof Technology \\ Sydney, Broadway, NSW 2007 , A ustralia \\ ${ }^{5}$ Strategic Water Infrastructure Laboratory, School of CivilM ining and Environmental Engineering, University of Wollongong, \\ Wollongong, NSW 2522 , A ustralia \\ * NguyenCongNguyen thientueminh11@gmail.com; Shiao-Shing Chenf10919@ntut.edu.tw; Huu Hao Ngo
} h.ngo@uts.edu.au

\begin{abstract}
Forward osmosis (FO) has emerged as a viable technology to alleviate the global water crisis. The greatest challenge facing the application of FO technology is the lack of an ideal draw solution with high water flux and low reverse saltflux. Hence, the objective of this study was to enhance FO by lowering reverse salt flux and maintaining high water flux; the method involved adding small concentrations of $\mathrm{Al}_{2}\left(\mathrm{SO}_{4}\right)_{3}$ to a $\mathrm{M} \mathrm{gCl}_{2}$ draw solution.

Results showed that

$0.5 \mathrm{M} \quad \mathrm{MgCl} 1_{2} \mathrm{mixed}$ with $0.05 \mathrm{M}$ of $\mathrm{Al}_{2}\left(\mathrm{SO}_{4}\right)_{3}$ at $\mathrm{pH} \quad 6.5$ achieved a lower reverse salt flux $(0.53 \mathrm{gM} \mathrm{H})$ than that of pure $\mathrm{MgCl}_{2}(1.55 \mathrm{gM} \mathrm{H})$ using an FO cellulosetriacetatenonwoven (C TA-N W ) membrane. This was due possibly to the flocculation of alum inum hydroxide in the mixed draw solution that constricted m em brane pores, resulting in reduced salt diffusion. M oreover, average water fluxes of 4.09 and $1.74 \mathrm{~L} /$ $\mathrm{m}^{2}$ - $\mathrm{h}$ ( L M H ) were achieved over $180 \mathrm{~m}$ in, respectively, when brackish water ( $5 \mathrm{~g} / \mathrm{L})$ and sea water $(35 \mathrm{~g} / \mathrm{L})$ were used as feed solutions. Furtherm ore, three types of mem branedistillation (M D) membranes were selected for draw solution
\end{abstract}

recovery; of these, a polytetrafluoroethylene membrane with a pore size of $0.45 \mu \mathrm{m}$ proved to be the most effective in achieving a high salt rejection (99.90\%) and high water flux $(5.41 \mathrm{~L} \mathrm{M} \mathrm{H})$ in a diluted draw solution.

K eyw ords Forward osmosis D Daw solution D Desalination Flocculation.M embranedistillation. Seaw ater

\section{Introduction}

Desalination has become a pragmatic approach to augment fresh water supplies in many coastal areas around the world (K hawaji et al. 2008 ). Large-scale desalination processes using thermal distillation (e.g., multi-stage flash and multieffect distillation) or reverse osmosis ( R O ) have been widely applied to extract fresh water from brackish or seawater for fresh water provision (Schiermeier 2008 , Semiat 2008). Thermaldistillation desalination processes involve the phase 
change of water from liquid to vapor and vice versa to obtain desalted water; thus, they consume huge amounts of energy (i.e., mostly in the form of heating) to produce a volume of fresh water. In contrast, R O desalination exploits a high hydraulic pressure that pushes liquid water through a semiperm eable membrane. The R O membrane is permeable to water while retaining all particulates, virus, bacterium, and mostly dissolved salts (Elimelech and Phillip 2011). A s a result, R O can produce fresh water directly from brackish or seawater with a significantly reduced energy consumption when com pared to the therm al distillation processes. It is, how ever, noteworthy that Ro desalination requires high-pressure pumps (i.e., hence, costly duplex stainless steel tubing), and is highly susceptible to membrane fouling, thus involving considerable feed water pre-treatmentand process maintenance.

Forward osmosis (FO) embodies notable attributes that render it a viable alternative to thermaldistillation or R O for desalination applications. In FO, liquidwaterisextracted from a saline solution feed using a sem ipermeablem embraneand a highly concentrated draw solution (A chilli et al. 2010 ; Nguyen et al. 2016 ; N guyen et al. 2013 ). Unlike in R O, the transport of fresh water through the membrane in FO is driven by the osmotic pressure difference between the feed and draw solutions. Consequently, Fo desalination processes can be operated at a moderate hydraulic pressure, which obviates the need for high-pressure pumps and duplex stainless steel tubing as required by RO. M ore importantly, given the absence of a high hydraulic pressure, FO candirectlyfiltersaline feed solutions with less fouling propensity compared to R O. M embranes used in Fo processes are also highly selective and therefore offer a high rejection of a wide range of contaminants as achieved by R O

D raw solution plays a vital role in an FO desalination process (A chilli et al. 2010 ; Hau et al. 2014). During the FO process, salts from the draw solution reversely permeate through the membrane to the feed solution coincidentally with the transportof fresh waterfrom the feed to the draw solution. The reverse salt flux results in a reduction in the osmotic pressure gradient acrossthe Fo mem brane, thus reducing process water flux. The reverse diffusion of draw solutes to the feed solution also entails the subsequent replenishment of the draw solution to sustain the FO process water flux. Thus, an idealdraw solution is expected to offer high waterflux with a lim ited salt reverse diffusion. In addition, it is worth noting that FO must be coupled with another process for the regeneration of the draw solution and simultaneous extraction of fresh water. The draw solution regeneration process largely determines the energy consumption of the FO desalination process. Therefore, an ideal Fo draw solution is also desired to be effectively regenerated w ith low energy requirements.

In recent decades, intensive studies have been conducted on Fo draw solutions exploitation and their regeneration methods (Table S 1 ). Notable examples include the study undertaken by M cCutcheon et al. (2006). Using $1.6 \mathrm{M}$ $\mathrm{N} \mathrm{H}_{4} \mathrm{HCO}_{3}$ as a draw solution, an FO process with a 29.25 g/L N aClsolution feed could achieve a high waterflux ( $J_{w}$ ) of $10.08 \mathrm{~L} \cdot \mathrm{m}^{-2} \cdot \mathrm{h}^{-1}(\mathrm{M} \mathrm{cCutcheon}$ et al. 2006$)$. The diluted $\mathrm{NH}_{3}$ / $\mathrm{CO}_{2}$ draw solution could be effectively regenerated using a low-tem peraturedistillation process and requiring relatively low energy consumption. However, a significant salt reverse flux (i.e., $J_{\mathrm{s}}=18.20 \mathrm{gM} \mathrm{H}$ ) was observed during the FO process when using $0.67 \mathrm{M} \mathrm{N} \mathrm{H}_{4} \mathrm{HCO}_{3}$ as a draw solution due to the small sizes of mono valent ions ( $\mathrm{NH}_{4}, \mathrm{HCO}_{3}$ ) ( $\mathrm{Achilli}^{-}$ et a 1.2010$)$. The reason was that the monovalent ions $\left(\mathrm{N} \mathrm{H}_{4}^{+}\right.$, $\mathrm{HCO}_{3}{ }^{-}$) in draw solution was easy to reversely permeate through the FO membrane. To overcome this issue, Tan and $\mathrm{Ng}(20010)$ used divalent salts ( $\mathrm{MgSO}_{4}$ and $\mathrm{CaCl}_{2}$ ) as the FO draw solutes and reported a significantly lower salt reverse flux as compared to the process using $\mathrm{NH}_{4} \mathrm{HCO}_{3}$. The divalent salt draw solution was subsequently regenerated by a nanofiltration (N F) process. However, the N F processdem onstrated a limited saltrejection at high $\mathrm{MgSO}_{4}$ and $\mathrm{CaCl}_{2}$ concentrations, thus inevitably leading to draw solution loss. Hau et al. (2014) employed ethylenediam inetetraacetic acid (ED TA) as a draw solution in an FO nanofiltration (FO-N F) hybrid system. The favorable solubility of EDTA in water helped the FO process achieve a noticeably high water flux (i.e., $12.60 \mathrm{~L} / \mathrm{m}^{2}$-h (L M H ) with a $0.7-\mathrm{M}$ EDTA draw solution). Nevertheless, The FO process with ED TA draw solution experienced a high $\mathrm{Na}^{+}$reverse flux, and the NF processcould remain only $93 \%$ of ED TA during its regeneration. Sim ilar to ED TA, polyelectrolytes of a series of polyacrylic acid sodium salts (PAA-Na) were also explored given their high water solubility (Ge et al. 2012 ). Recently, several new draw solutes, including synthesized magnetic nanoparticles, hydrolyzed poly (isobutylene-alt-maleic acid), hexavalent phosphazene, and 2 -methylimidazole-based organic compounds, have been tested for FO (Bai et al. 2011 ; Ge et al. 2014 ; Kumar et al. 2016 ; Ling et al. 2010 ; Lutchmiah et al. 2014 ; Stone et al. $2013 \mathrm{a}$; Stone Stone et al. $2013 \mathrm{~b}$; Yen et a1. 2010$)$. A lthough these draw solutes could be great potential in application, synthesizing the solutes is costly and recovery of the draw solutions is complex, consequently motivating the author to carry out this work. In this study, a novel draw solution for minimizing the reverse flux of ions during Fo desalination to decrease the cost for replenishing lost draw solute.

This study aim s to elucidate the feasibility of abrackishand seawater FO desalination process using a noveldraw solution coupled with a membrane distillation (M D) process for its regeneration. The proposed noveldraw solution was prepared by adding low $\mathrm{Al}_{2}\left(\mathrm{SO}_{4}\right)_{3}$ concentration into $\mathrm{M} \mathrm{gCl}_{2}$ solution. It was hypothesized that flocculated aluminum at optimal pH values in the draw solution could absorb ions and form an additional layer on the FO mem brane surface, thus alleviating the reverse flux of the draw solutes to the seawater feed. Therefore, the influences of the draw solution pH and 
concentration on the FO process performance were first system atically evaluated using deionized (D I) water as the feed solution. Then, the FO desalination process with brackish water and seawater feeds using the novel draw solution was dem onstrated. Finally, the regeneration of the proposed Fo draw solution using an M D process was scrutinized. As a thermally driven m em brane separation process, M D was envisaged to offerviable, low-cost draw solution regeneration to the FO process.

\section{Materials and methods}

\section{The draw and feed solutions}

The draw solution was prepared by dissolving mixtures of laboratory-grade $\mathrm{M} \mathrm{gCl}_{2}:_{\mathrm{Al}_{2}}\left(\mathrm{SO}_{4}\right)_{3}$ ( $\mathrm{Merck} \mathrm{Co}$., Ltd., Germany) at molar ratios of $2: 1,6: 1,10: 1, \quad 14: 1$, and $20: 1$ in DI water at room temperature. The pH of the draw solution was then adjusted to 2.9 to $3.5,5.0,6.5$, and 7.0 using $\mathrm{NaOH}$. The prepared draw solutions were continually stirred for $24 \mathrm{~h}$ prior to all Fo experiments.

D I water and synthetic brackish water and seawater were used as feed solutions. D I water was used in the experiments to determ ine the optimal pH and concentration of the Fo draw solutions. Synthetic brackish water and seawater were em ployed in the desalination demonstration of the FO process. The specifications of these feed solutions were provided in Table 1

\section{FO and MD membranes}

Cellulose triacetate (C TA) nonwoven membrane $(15 \times 22 \mathrm{~cm})$ obtained from H ydration Technology Innovations ( H T Is O sM em TM C T A membrane 121204 , A lbany, OR, U SA) was utilized for the FO setup. The FO membrane had an active layer on the top of a support layer and had a total thickness of $50 \mu \mathrm{m}$. The FO membrane was relatively hydrophobic (Jin et al. 2012 ; $X$ ie et al. 2012 a) with the determined contact angle of $60^{\circ}-80^{\circ}$. In addition, at $\mathrm{pH}>4.5$, it was negatively charged ( $\mathrm{X}$ ie et al. $2012 \mathrm{~b})$.

Three types of polytetrafluoroethylene (PTFE) membranes from Ray-E Creative Co., Ltd. (Taiwan) were employed for the M D setup. Their pore sizes and contact angles are given in Table 2 .

Table 1 Properties of synthetic brackish water and seaw ater as feed solutions
Table 2 Pore size and contactangle of PTFE m e mbranes used for $\mathrm{m}$ e $\mathrm{m}$ brane $\mathrm{d}$ is tillation

\begin{tabular}{lll}
\hline M e mbrane & Pore size $(\mu \mathrm{m})$ & \\
\hline PTFE \#1 & 0.1 & $126 \pm 5$ \\
PTFE \#2 & 0.45 & $114 \pm 4$ \\
PTFE \#3 & 1.0 & $126 \pm 2$ \\
\hline
\end{tabular}

\section{The lab-scale hybrid FO-MID system}

The FO-M D hybrid system used in this study consisted of FO and M D m embrane cells, FO feed and draw solution tanks, and a M D distillate reservoir (Fig. 1). The FO membrane cell (FO Sterlitech) had two sym metric channels with width, length, and height of 4.5 , 9.2 , and $0.2 \mathrm{~cm}$ respectively, generating an effective m em brane area of $41.40 \mathrm{~cm}^{2}$ for mass transfer. Similarly, the M D membrane cell (Ray-E Creative Co., Ltd., Taiwan) was also composed of two channels having width, length, and height, respectively, of 10.0 , 10.0 , and $0.3 \mathrm{~cm}$. The active membrane surface for M D m ass transfer was $100 \mathrm{~cm}^{2}$.

In this study, the FO and M D systems were operated separately to optimize desalination process. The feed solution ( $500 \mathrm{~mL})$ and the draw solution $(1000 \mathrm{~mL})$ at room temperature $\left(25{ }^{\circ} \mathrm{C}\right)$ were circulated through the FO cell under the same flow rate using two peristaltic pumps (M aster Flux L/S D rive, M odel 7518-00) (Fig. 2). Conductivity and pH of the feed and the draw solution were regularly measured using sensors submerged in the solutions. The feed solution tank was placed on digital we ighing scales ( B W $12 \mathrm{~K} \mathrm{H}$, Shim adzu, Japan) connected to a computer for water flux measurements. Under the osmotic pressure difference across the Fo membrane, water from the feed solution was transferred through the membrane and diluted with the draw solution.

The diluted draw solution was then regenerated using the M D setup (Fig. 3). During the M D regeneration, the diluted draw solution was heated to $55{ }^{\circ} \mathrm{C}$ and circulated through the M D feed channel. D I water (at $25{ }^{\circ} \mathrm{C}$ ) was circulated on the other side of the membrane to condense water vapor permeated through the membrane from the diluted solution. The M D feed and distillate circulation rates were $0.083 \mathrm{~m} / \mathrm{s}$. The excess water from

(a)

\begin{tabular}{|c|c|c|c|}
\hline Feed solutions & Total d is solved solid, p pm & $V$ iscosity, c p & Osmotic pressure, \\
\hline b ar B rack ish water $(5 \mathrm{~g} / \mathrm{L} \mathrm{N}$ aC 1$)$ & 5000 & 0.96 & 4.02 \\
\hline Seaw ater $(35 \mathrm{~g} / \mathrm{L} \mathrm{N}$ a C 1$)$ & 35,000 & 1.14 & 27.78 \\
\hline
\end{tabular}




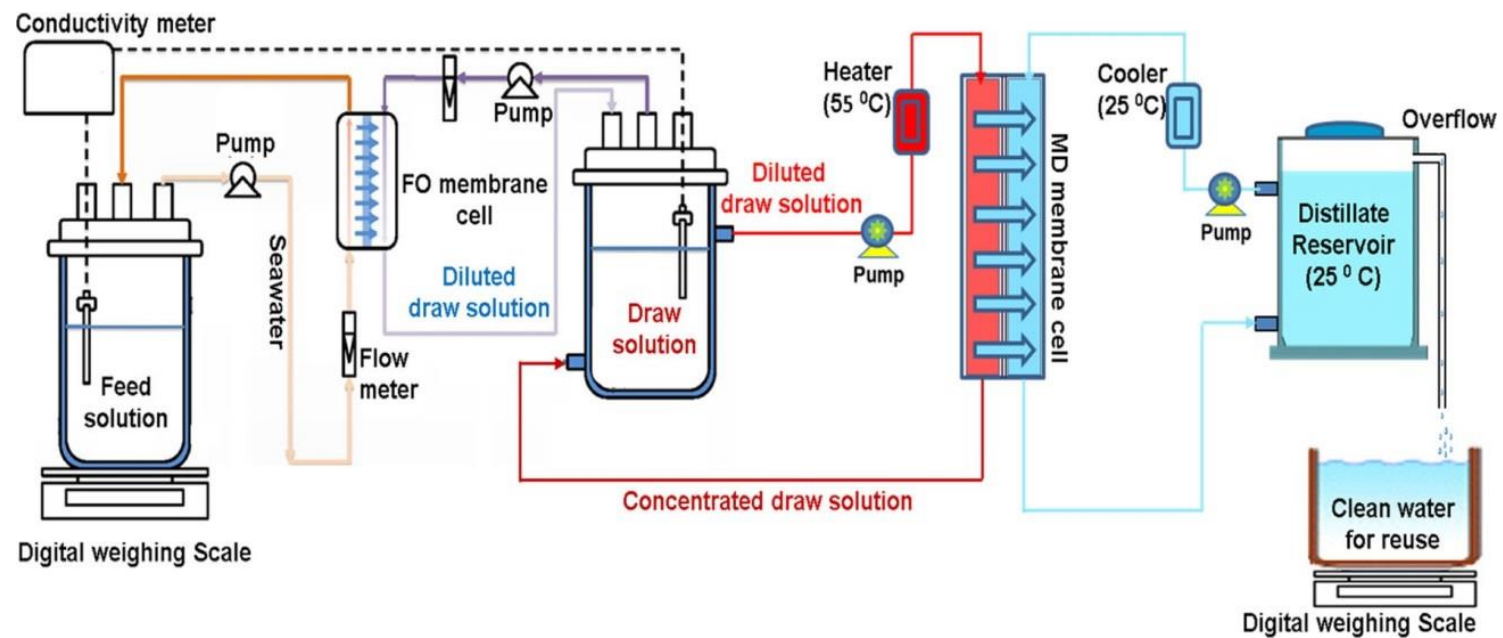

Fig. 1 A schematic diagram of the lab-scale FO-M D hybrid system

the distillate tank was regularly weighted for M D water flux m easurement.

\section{Analytical methods}

FO waterflux $\left(J_{w}\right)$ was calculated as follows:

$J_{w}=\frac{\Delta V}{A \Delta t}$,

where $J_{w}$ was in $L / m^{2}$ - h ( L M H ), $\Delta$ V w as the feed volume change overa time interval $\Delta \mathrm{t}$ (hours), and A w as the effective FO membrane area $\left(\mathrm{m}^{2}\right.$ ). The reverse solute flux $\mathrm{J}_{\mathrm{s}}$, (in $\mathrm{g} / \mathrm{m}^{2}$ h) of draw solution, was determ ined by the conversion of its electrical conductivity measured by a conductivity meter when $\mathrm{M} \mathrm{gCl}_{2}$ and $\mathrm{Al}_{2}\left(\mathrm{PO}_{4}\right)_{3}$ salt dissociated in its aqueous solution as follows:

$J_{s}=\frac{V_{t} C_{t}-V_{0} C_{0}}{A t}$,

Fig. 2 A photo of the FO setup for desalination of se a w a ter where $\mathrm{C}_{\text {t }}$ and $\mathrm{V}$, were the concentration and volum e of the feed solution, respectively, measured at time t, and $\mathrm{C}_{0}$ and $\mathrm{V}_{0}$ were the initialconcentration and volum e of the feed solution.

The specific reverse saltflux ( $J_{s} / J_{w}$ in $\left.g / L\right)$, which was the ratio of salt flux $J_{s}$ and water flux $J_{w}$, was used to determine the am ount of draw solute lossper a unit volume of produced water during an FO process.

The performance of the M D processfor regeneration of the draw solution was evaluated using the process water flux and salt rejection. M D waterflux was determined sim ilarly to FO waterflux, while M D salt rejection (R) w as calculated using Eq. (3):

$\mathrm{R}^{1 / 4} 1-\frac{\text { EC }_{\text {distillate }}}{\text { E C }_{\text {feed }}} 100 \%$

where $E_{\text {distillate }}$ and $E C_{\text {feed }}$ were the conductivity of the M D distillate and feed, respectively.

Viscosity and conductivity of the feed and draw solutions were determ ined using a Vibro Viscometer (A D

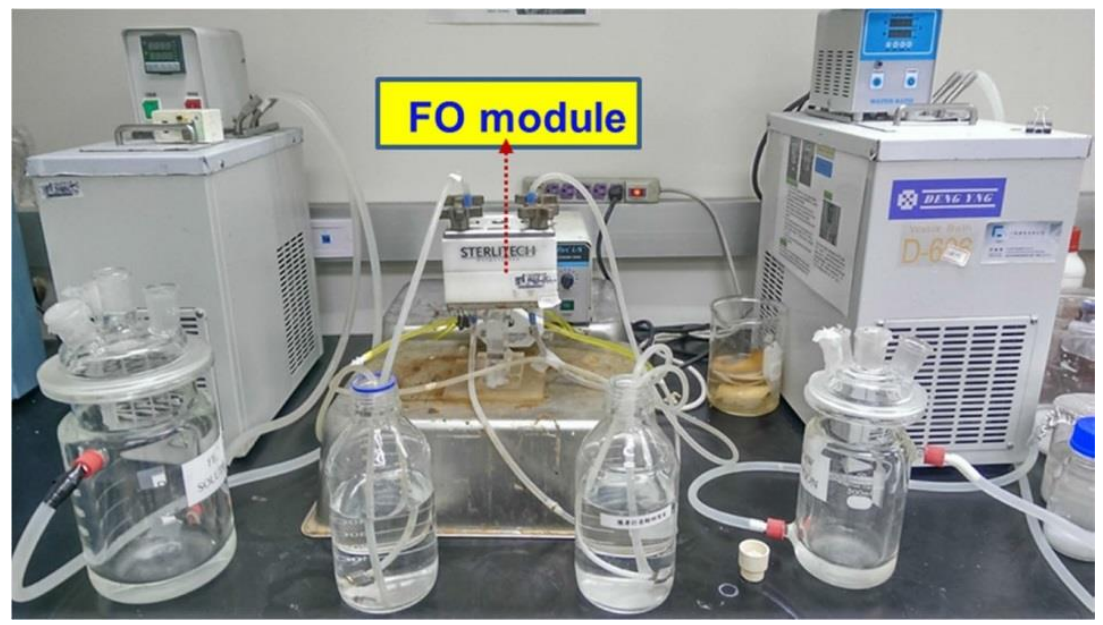


Fig. 3 A photo of the M D

setup forw ater recovery

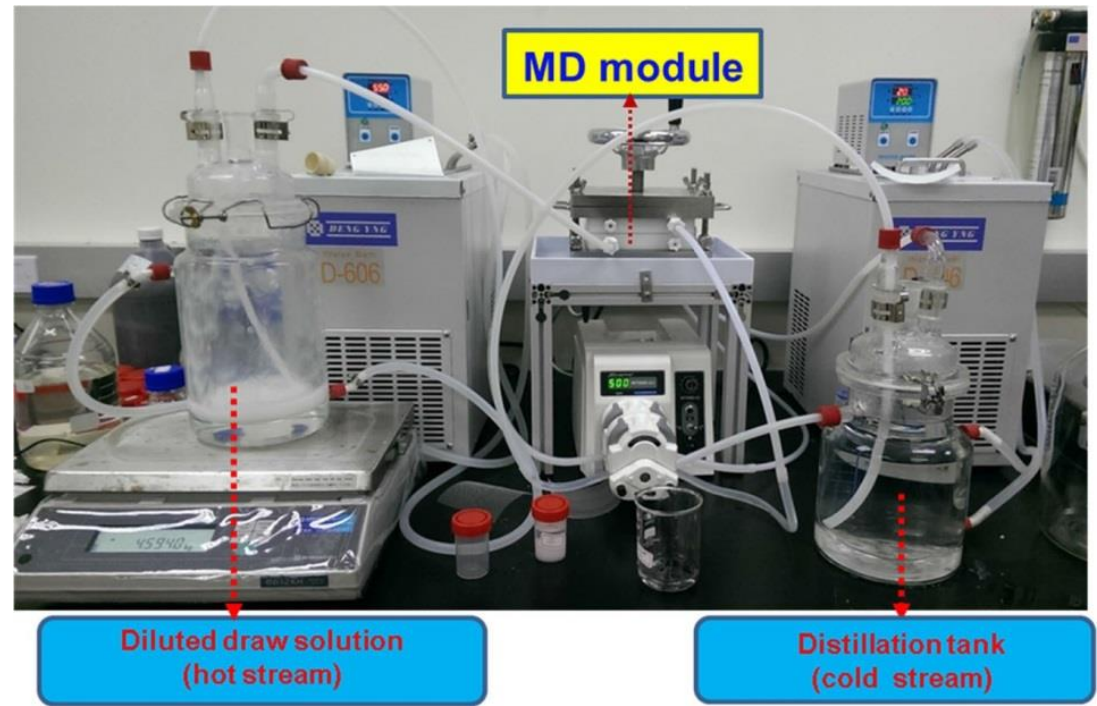

Company, Japan) and conductivity meter (SensION156,

$\mathrm{Hach}$, C hina). The contact angles of the M D membranes were measured using the sessile drop method (i.e., droplet volume of $10 \pm 1 \mu \mathrm{L}$ ) on a C A M 100 (OptoM echatronics P Ltd., India). A 11 m easurements were conducted at room temperature $\left(25^{\circ} \mathrm{C}\right)$. The concentrations of $\mathrm{Mg}^{2+}, \mathrm{Cl}^{-}, \mathrm{Al}^{3+}$, and $\mathrm{SO}_{4}{ }^{3-}$ were analyzed using ion chromatography (D ionex ICS-90) and an ultraviolet-visible spectrophotometer ( $\mathrm{H} \mathrm{ACH} \mathrm{M} \mathrm{odel}$ D R-4000, Japan). The osmolality of the solutions was m easured using an osmometer (model 3320 , Advanced Instruments, Inc., U SA), based on the freezing-point depression method (Gadelha et al. 2014). The draw solution's particle size was measured using a nanoparticle analyzer (S Z-100, H oriba, Japan).

\section{Results and discussion}

\section{Effect of pH on water flux and reverse salt flux}

The values of waterflux, reverse saltflux, specific reversesalt flux, and osmolality corresponding to differentpH values of draw solution are shown in Figs. 4 and 5 . D I water was em ployed as a feed solution, $0.5 \mathrm{M} \mathrm{M} \mathrm{g} \mathrm{C} \mathrm{I}_{2}+0.05 \mathrm{M}$ $\mathrm{A}_{2}\left(\mathrm{SO}_{4}\right)_{3}$ was used as draw solution for the initial experiment. The initial pH of the given draw solution was found to be 2.87 .

The waterflux increased from 4.01 to $4.79 \mathrm{LM} \mathrm{H}$ in the FO mode (w ith the active layer facing the feed solution) and from 7.30 to $8.92 \mathrm{LM} \mathrm{H}$ in the pressure retarded osmosis (PRO) mode (w ith the active layer facing the draw solution) as the
Fig. 4 E ffect of pH on waterflux and reverse salt flux. Feed solution: D I water, draw solution $0.5 \mathrm{M} \mathrm{M} \mathrm{gCl} 2+0.05 \mathrm{M}$ A $12\left(\mathrm{SO}_{4}\right) 3$, flow rate: $0.5 \mathrm{~L} / \mathrm{m}$ in,

experimentduration: 1 h

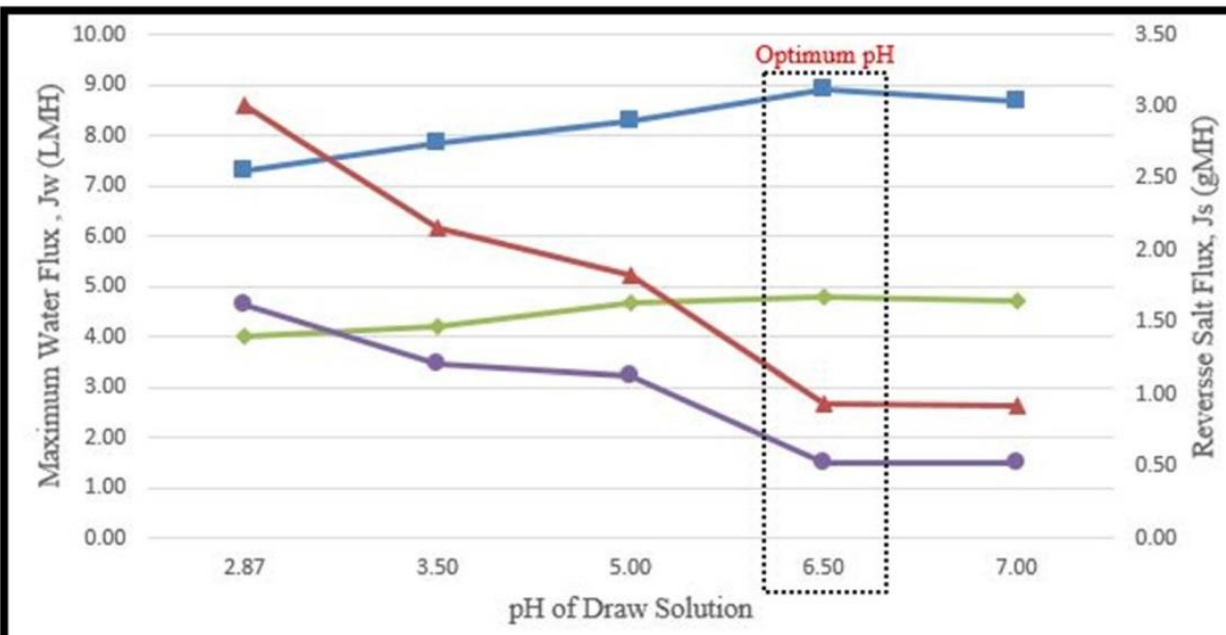

-Jw_PRO mode vs pH $\quad \longrightarrow$ Jw_FO modevs pH $\quad \longrightarrow$ Js_PRO mode vs pH $\longrightarrow$ Js_FO mode vs pH 
Fig. 5 Effect of pH on and osmolality. Feed solution: D I water, draw $0.05 \mathrm{M} \mathrm{Al}_{2}\left(\mathrm{SO}_{4}\right)_{3}$, flow rate: $0.5 \mathrm{~L} / \mathrm{m}$ in,

experimentalduration: 1 h specific reverse salt flux solution: $0.5 \mathrm{M} \mathrm{M} \mathrm{gCl} \mathrm{C}_{2}+$

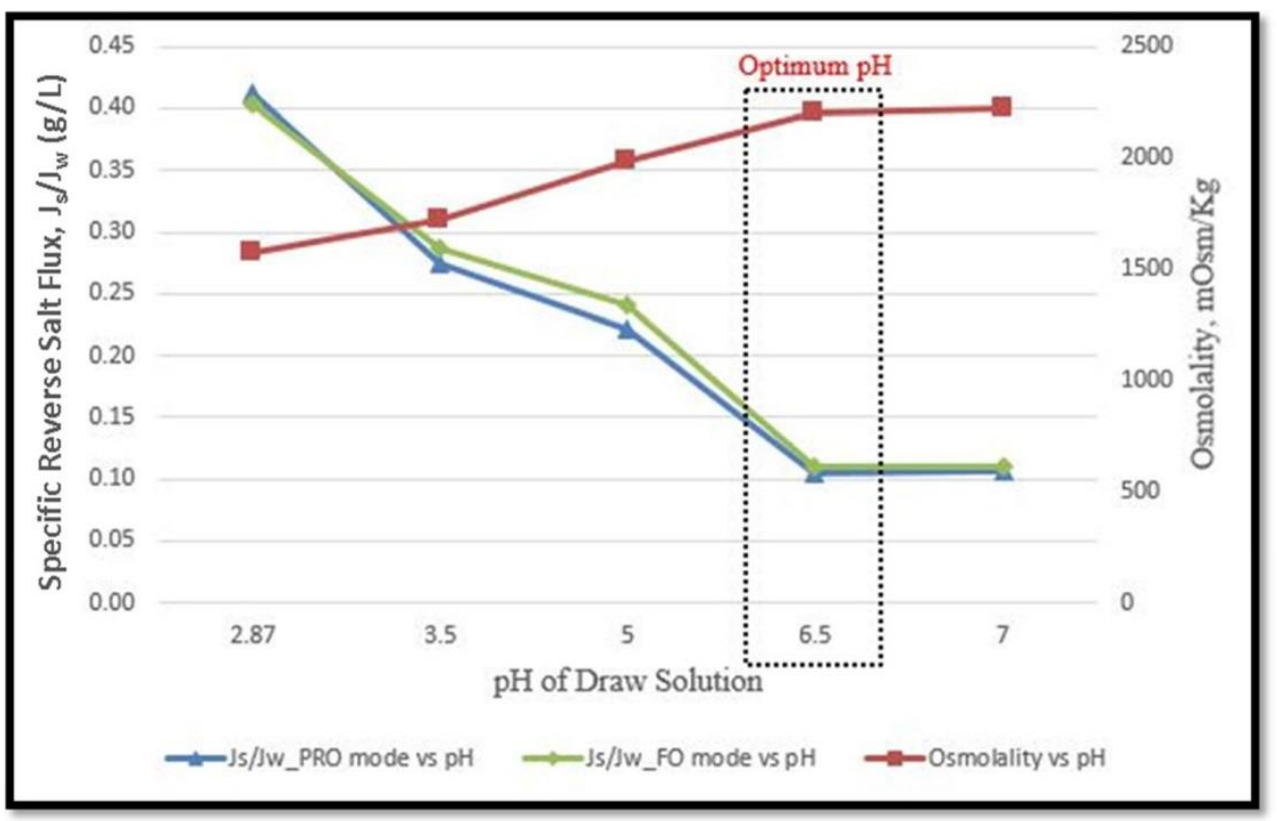

pH is increased from 2.87 to 6.50 . This can be explained as follow s: the addition of $\mathrm{NaOH}$ increased the osmolality of the draw solution. A lso, the reverse salt flux decreased from 1.62 to $0.52 \mathrm{gM} \mathrm{H}$ in the FO mode and from 3.01 to $0.92 \mathrm{gM} \mathrm{H}$ in the PRO mode as the pH increased from 2.87 to 6.50 .

This was due to a large amount of flocculation of alum inum hydroxide in the mixed draw solution at pH 6.50 (particle sizes of draw solution was large shown in Figure S1) that formed as a second layer on the FO membrane and constricted membrane pores, resulting in reduced salt diffusion (Figure S2). As the pH increased from 6.50 to 7.00 , the water flux started to decrease in both FO and PRO modes, as shown in Fig. 4. The decrease was due to excess formation of flocculation in the draw solution, which led to an increase in the solution's viscosity and thus to a decrease in the water flux. Therefore, the optimum pH condition for $0.5 \mathrm{M} \quad \mathrm{MgCl}_{2}+0.05 \mathrm{M} \mathrm{Al}_{2}\left(\mathrm{SO}_{4}\right)_{3}$ in both the FO and PRO modes was found to be 6.5. The osmolality of the draw solution corresponding to the opti$\mathrm{mum} \quad \mathrm{pH}$ was $2200 \mathrm{mosm} / \mathrm{kg}$.

A $t$ a $\mathrm{pH}$ of 6.5 , the water flux and reverse salt flux

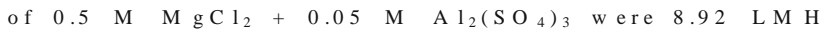
and $0.94 \mathrm{gMH}$, respectively, in PRO mode. When only $0.5 \mathrm{M} \mathrm{MgCl} \mathrm{l}_{2}$ was used, the water flux and reverse salt flux were $8.27 \mathrm{LMH}$ and $2.76 \mathrm{gMH}$, respectively, in PRO mode. Therefore, when $0.05 \mathrm{M} \quad \mathrm{Al}_{2}\left(\mathrm{SO}_{4}\right)_{3}$ is added to the draw solution, the reverse salt flux decreases to a great extent due to the formation of flocculation, as discussed earlier.
Fig. 6 Effect of draw solution concentration on water flux and specific reverse salt flux. Feed solution: D I w ater, draw solution: various $\mathrm{M} \mathrm{gCl}_{2}$ concentrations from 0.1 to 1 M coupled with a fixed $\mathrm{A}_{2}\left(\mathrm{SO}_{4}\right)_{3}$ concentration of $0.05 \mathrm{M}$, flow rate: $0.5 \mathrm{~L} / \mathrm{m}$ in, experimentalduration: 1 h

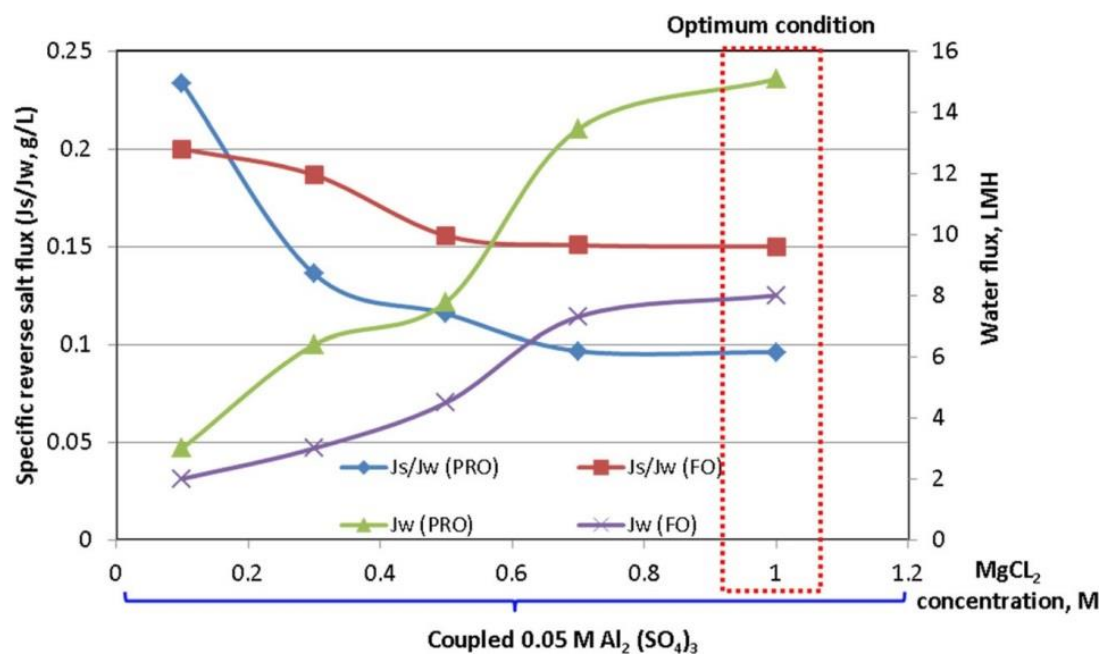


Fig. 7 Effect of draw

solution concentration on viscosity and osmolality

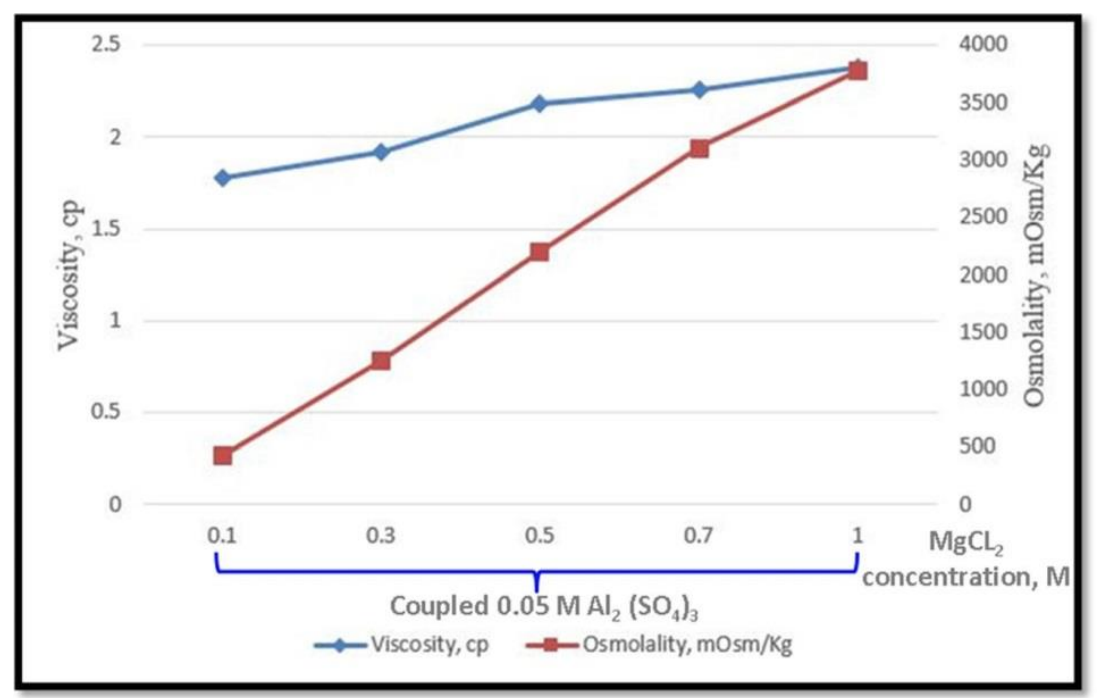

Effect of draw solution concentration on water flux and reverse salt flux

Figures 6 and 7 illustrate the reverse salt flux, water flux, viscosity, and osmolality for five draw solutions with various $\mathrm{M} \mathrm{gCl} \mathrm{I}_{2}$ concentrations (from 0.1 to $1 \mathrm{M}$ ) coupled with a fixed $\mathrm{A}_{2}\left(\mathrm{SO}_{4}\right)_{3}$ concentration of $0.05 \mathrm{M}$. A s shown in Fig. 6 , the water flux increased from 3.15 to 15.09 LM H in the PRO mode and from 1.71 to 8.18 LM H in the FO mode as the concentration of $\mathrm{M} \mathrm{gCl}_{2}$ increased from 0.1 to $1 \mathrm{M}$. This can be explained by the sharp increase in the sample's osmolality. A 1 so, the reversesalt flux increased from 0.52 to $2.65 \mathrm{gM} \mathrm{H}$ in the PRO mode and 0.299 to $1.61 \mathrm{gM} \mathrm{H}$ in the FO mode because of the increase in $\mathrm{Mg}^{2+}$ ions in the draw solution. Thus, the higher concentration of $\mathrm{MgCl}_{2}$ in the draw solution achieved a higher water flux; however, the nonlinearity of the variation of water flux with respect to the concentration was due to the effects of viscosity and internal concentration polarization ( Fig. 7).

Figure 6 show that 1 M $\quad \mathrm{M} \mathrm{gCl}_{2}$ coupled with $0.05 \mathrm{M}$ $\mathrm{Al}_{2}\left(\mathrm{SO}_{4}\right)_{3}$ as draw solution achieved the lowest specific reverse salt flux $\left(\mathrm{J}_{\mathrm{s}} / \mathrm{J}_{\mathrm{w}}=0.096 \mathrm{~g} / \mathrm{L}\right.$ in $\mathrm{PRO}$ and $\mathrm{J}_{\mathrm{s}} / \mathrm{J}_{\mathrm{w}}=0.151 \mathrm{~g} / \mathrm{L}$ in $\left.\mathrm{FO}\right)$. This clearly demonstrated that a molar ratio of $\mathrm{MgCl}_{2}$ / $\mathrm{Al}_{2}\left(\mathrm{SO}_{4}\right)_{3}=20$ was the optimal condition for the draw solution.
Forward osmosis desalination process

To compare the efficiency levels of the desalination process with various feed solutions, three different feed solutions were used: D I water, brackish water (total dissolved solid ( T D S ) = $5000 \mathrm{ppm}$, and sea water $(\mathrm{T} \mathrm{DS}=35,000 \mathrm{ppm}) ; 1 \mathrm{M} \mathrm{MgCl}_{2}+0.05 \mathrm{M}$ $\mathrm{A}_{2}\left(\mathrm{SO}_{4}\right)_{3}$ was used as a draw solution for desalination.

Figures S 2 and S 3 show the water flux decreased quickly in both FO and PRO modes when the osmotic pressure gradient between the draw and feed solutions decreased. During the first $30 \mathrm{~min}$ of the Fo process, the D I water used as a feed solution achieved the highest water flux $\left(J_{w}=15.12 \mathrm{~L} / \mathrm{m}^{2} \mathrm{~h}\right.$ in $P R O \quad m o d e$ and $J_{w}=8.09 \mathrm{~L} / \mathrm{m}^{2} \mathrm{~h}$ in FO mode), followed by brackish water with a TD S of 5000 ppm $\left(J_{w}=9.40 \quad L / m{ }^{2} \mathrm{~h}\right.$ in PRO mode and $J_{w}=5.03 \mathrm{~L} / \mathrm{m}^{2} \mathrm{~h}$ in $\left.\mathrm{FO} \operatorname{mode}\right)$, and sea water with TDS of 35,000 ppm $\left(J_{w}=3.95 \quad L / m{ }^{2} h\right.$ in PRO mode and $J_{w}=2.11 \quad \mathrm{~L} / \mathrm{m}^{2} \mathrm{~h}$ in $\left.\mathrm{FO} \quad \mathrm{mode}\right)$. When the desalination process was continued for additional time, the water flux was slightly decreased because of increases in the osmotic pressure of the feed solution ( Table S2), which indicated that membrane fouling was neglected.
Table 3 The effect of PTFE $m$ e $m$ brane poresizes in $M$ system on removalefficiencies and water flux fordiluted draw solu tion recovery

\begin{tabular}{|c|c|c|c|}
\hline M D m e m brane & Co nductivity in permeate $(\mu \mathrm{S} / \mathrm{cm})$ & Rejection (\%) & M D waterflux $J_{w}, L / m^{2} h$ \\
\hline P T F E \# 1 & $69.2 \pm 1.5$ & 99.93 & $4.95 \pm 0.11$ \\
\hline P T F E \# 2 & $93.8 \pm 1.9$ & 99.90 & $5.41 \pm 0.11$ \\
\hline P T FE \# 3 & $893.0 \pm 2.4$ & 99.06 & $5.70 \pm 0.12$ \\
\hline
\end{tabular}




\section{Recovery of diluted draw solution by membrane distillation}

A membrane distillation process was tested to recover the diluted draw solution for reuse in the FO process. The three P T FE membranes w ith different pore sizes were used to determ ine the most suitable membrane. The waterflux through these mem branes is shown in Table 3 . The results indicate that the highest w ater flux, 5.70 L M H, was achieved by the PTFE \# 3 of $1-\mu \mathrm{m}$ pore size. The water fluxes through the PTFE \#2 (pore size of $0.45 \mu \mathrm{m}$ ) and PTFE \#1 ( 0 pore size of $0.1 \mu \mathrm{m}$ ) m em branes were 5.41 and $4.95 \mathrm{~L} \mathrm{M} \mathrm{H}$, respectively. The water flux increased with increases in pore size as the pore radius influenced the vapor transport; thus, a high pore radius tends to result in a high water flux. This confirmed the study conducted by A dnan et al. (2012), which discussed the influence of pore size on M D flux. The rejection percentage was found to be close to $100 \%$ in the PTFE \# 1, PTFE \#2 (99.90\%), and PTFE \#3 (99.06\%) membranes. The reported result is consistent with previous studies by Duong et al. (2015), em phasizing the significant rejection of $M$ D membrane due to partial vapor pressure differences across the membrane. A s seen in Table 3, the difference in the water flux between the PTFE\#3 and PTFE\#2 membranes was not appreciable; however, the PTFE\# 2 m em brane retained a considerably higher am ount of ions. Hence, the PTFE \#2 membrane was found to be most suitable for recovery of draw solution through mem brane distillation with the conductivity rejection of approximately $100 \%$ and the concentration of conductivity in the permeate flux w as as low as $93.8 \mu \mathrm{S} / \mathrm{cm}$, respectively, which w as suitable forwater reuse and drinking water.

D iluted draw solution a s initial feed with T D S $=61,483 \mathrm{mg} / \mathrm{L}, \mathrm{EC}=95,300 \mu \mathrm{S} / \mathrm{cm}$, and $\mathrm{pH}=6.5$. Errors were based on the standard deviations of three replicate tests of the three independent M D m embranes.

Con clusions

A successfulapplication of $1 \mathrm{M} \mathrm{M} \mathrm{gCl} 1_{2}$ coupled with $0.05 \mathrm{M}$ $\mathrm{A}_{2}\left(\mathrm{SO}_{4}\right)_{3}$ as a draw solution in a forward osmosis desalination process was dem onstrated. The high solubility of the salt and flocculation created by $\mathrm{A}_{2}\left(\mathrm{SO}_{4}\right)_{3}$ not only provided a high osmotic pressure for high water flux but also led to a reduced reverse salt flux as compared with numerous other in organic salts. The chosen draw solution was able to desalinate brackish and sea waterat water flux values of 4.09 and $1.74 \mathrm{~L} \mathrm{M} \mathrm{H}$, respectively, using a C TA nonwoven (N W ) mem brane in FO mode. Furthermore, the PTFE \#2 membrane (pore size of $0.45 \mu \mathrm{m}$ ) was selected as the most suitable m em brane for recovering the diluted draw solutions with a solute rejection of approximately $100 \%$ and a M D water flux of $5.41 \mathrm{~L} \mathrm{M} \mathrm{H}$
A cknowledgments This work was supported by the Southern Taiw an Science Park and the M inistry of Science and Technology of the R epublic of China under the grant number of 104-2221-E-027-004-M Y 3. The a uthorsare also gratefulfor the supportof the Institute of Environmental Engineering and M anagement, N a tional Taipei U n iversity of Technology, Taiw an and Centre for Technology in W ater and W astew ater, U niversity of Technology, S y d ney, A ustralia.

\section{References}

A chilli A, C ath TY, Childress A E (2010) Selection of in organic-based d raw solutions for forward osmosis applications. J M e m brSci 364 : $233-241$

A d n an S, H o ang M, W a ng H, X ie Z ( $\left.\begin{array}{llll}2 & 0 & 1 & 2\end{array}\right)$ Com mercial P TFE m e m branes for membrane distillation application: effect of microstructure and supportm ate rial. Desalin ation 284:297-308

B a i H, Liu Z, S un D D (2011) Highly water soluble and recovered dextran co ated $\mathrm{Fe}_{3} \mathrm{O}_{4} \mathrm{~m}$ agnetic $\mathrm{n}$ an oparticles for brackish water desalination. Sep Pu rif Techno1 81:392-399

D uong H C, Cooper P, Nelemans B, Cath T Y, N ghiem LD (2 015 ) O p timising thermalefficiency of direct contact membrane distillation by brine recycling for small-scale seawater desalination. D e salination $374: 1-9$

Elimelech M, Phillip W A (20 1 1 ) The future of seawater desalination: en ergy,technology, and the environment. Sc ience $333: 712-717$

G ade lha G, N awaz M S, H ankins N P, K han S J, W ang R, Tang C Y (2014) A ssessment of micellar solutions as draw solutions for forward os mosis. D esalinatio n 354:97-106

G e Q, S u J, A m y G L, Chung T-S ( 2012 ) Ex ploration of polyelectrolytes as draw solutes in forward osmosis processes. Water R es 46:13181326

G e Q, Fu F, C hung T-S (2014) Ferric and cobaltous hyd roacid complexes for forward osmosis (FO) processes. W aterR es $58: 230-238$

H a u N T, Chen S-S, N guyen N C, H uang K Z, N go H H, G uo W (2 2014 ) Exploration of ED TA sodium salt as noveldraw solution in forward o s m osisprocessfor dewatering of high nutrientsludge.J M em br Sci $455: 305-311$

Jin X, S h an J, W ang C, Wei J, Tang C Y (2012) R ejection of pharmaceuticals by forwardosmosis membranes. J H azard M ater $227(28): 55-$ 61

K hawaji A D, K u tubkhanah IK, W ie J-M (2008) A dvances in seawater desalination technologies. Desalin ation 22 1:47-69

K u m ar R, A 1-Haddad S, A 1-Rughaib M, S alman M (2016) Evaluation of hy drolyzed poly (isobuty lene-alt-maleic an hydride) as a polyelectrolyte draw solution for forward osmosis desalination. Desalination $394: 148-154$

L in $g$ M M, W ang K Y, Chung TS ( 2010$)$ H ighly water-soluble magnetic nan oparticles as noveldraw solutes in forward osmosis for water reuse. Ind Eng Chem R es 4 9:5869-5876

Lutch m iah K, Lauber L, R oest K, H arm sen D JH, Post JW, Rietveld L C van L ier JB, Cornelissen E R ( 2014$) \mathrm{Z}$ w itterions as a lternative d raw solutions in forward osmosis for a p plication in w astew aterreclam ation. J M e m br Sci $460: 82-90$

M c Cutcheon JR, M c Ginnis R L, Elimelech M (2006) Desalination by a m monia-carbon dioxide forward osmosis: in fluence of draw and feed solution concentrations on process performance. J M embr Sci $278: 114-123$

N g u yen N C, Chen S S, Yang H Y, H a u N T (20 1 013 ) A p plication of forward osmosis on dewatering of high nutrient sludge. B io resour Technol $132: 224-229$

N gu yen N C, C hen S - S, N guyen H T, R ay S S, N go H H, G u o W, L in P-H (20 1 016 ) Innovative sponge-based moving bed-osmotic m embrane 
bioreactorhybrid system using a new classof draw solution for m unicipal wastew ater treatm ent. Water R es $91: 305-313$

$\mathrm{S} c h$ ie rmeier Q (2008) Water: purification w ith a pinch of salt. N ature 452 : 260-261

Sem iat R (2008) Energy is sues in desalination processes. Environmental Science \& Technology 42:8193-8201

S to ne M L, R ae C, S tew a rt FF, W ilson A D (2013b) Sw itchable polarity solvents as draw solutes for forward osmosis. Desalination 312 : $124-129$

S to ne M L, W ils on A D, H arrup M K, S tew art F F (2013 a) A n in itialstudy of hexavalent phosphazenesalts as draw solutes in forwardosmosis. D e salination $312: 130-136$
Tan CH, N g H Y (2010) A novel hybrid forward osmosis-nanofiltration (F O - N F) process forseawaterdesalination: draw solution selection and system configuration. D esalin W ater Treat 13:356-361

$\mathrm{X}$ ie M, N g h iem L D, Price W E, E limelech M (2 012 a) C o mparison of the rem ovalof hydrophobic trace organic contam inantsby forward os mosis andreverse osmosis. W ater R es 4 6:2683-2692

$\mathrm{X}$ ie M, Price W E, N ghiem L D ( 2012 b) R ejection of $\mathrm{pharm}$ aceutically active compounds by forward osmosis: role of solution pH and m e m brane orientation. S e p Purif Technol 93:107-114

Yen S K, M ehnas Haja N F, S u M, W ang K Y, Chung T-S ( 2010 ) S tudy of d raw solutes using 2 -m eth y lim idazole-based com pounds in forw ard osmosis. J M em br Sci3 64:242-252 